\title{
Edgar and the eight kings, AD 973: textus et dramatis personae David E. Thornton
}

The purpose of the paper is to examine in detail the alleged submission by Welsh, Scottish and Scandinavian rulers to the English king Edgar at Chester in 973, and particularly the claim made in a number of AngloNorman chronicles that these rulers rowed Edgar up and down the River Dee as part of this submission. All relevant texts (both explicit descriptions and possible allusions) will be presented and analysed, and the identities of the Celtic and Scandinavian rulers will be considered. The paper will argue that the rowing episode is a post-Conquest fictional embellishment based on earlier Old English material, and that the meeting at Chester in 973 was a 'peace summit' rather than a straightforward submission.

One of the more colourful episodes in the relations of tenth-century English kings with their Celtic neighbours is the submission of various Scottish, Welsh and Scandinavian rulers to Edgar 'Pacificus' at Chester, shortly after his coronation as king of England at Bath on Whit Sunday (II May) 973. Accounts from the twelfth century and later state that these rulers not only submitted to Edgar's lordship but also rowed him up and down the River Dee. Modern scholarly opinion on this episode has varied: while some historians have denied that the accounts of the submission in 973 had any basis in fact, others have accepted them as wholly historical. ${ }^{.}$I propose to re-examine the submission of 973 by presenting all the texts (both pre- and post-Conquest) which refer to it and discussing the identity of the kings who allegedly took part. Only through a detailed examination and comparison of these texts can the development and historical value of this intriguing episode be understood.

I E.W. Robertson, Scotland under her Early Kings: a History of the Kingdom to the Close of the Thirteenth Century, 2 vols (Edinburgh, I862), II, 384-7; W.H. Stevenson, 'The Great Commendation to King Edgar in 973, Wales from the Earliest Times to the Edwardian Conquest, 2 vols, 3rd edn (London, 1939), I, 349-50; F.M. Stenton, Anglo-Saxon England, 3rd edn (Oxford, I97I), pp. 368-70; and, most recently, B.T. Hudson, Kings of Celtic Scotland (Westport, CT., I994), pp. 97-8.

Early Medieval Europe 200 Io (I) 49-79 (C) Blackwell Publishers Ltd 200I, I08 Cowley Road, Oxford $\mathrm{OX}_{4}$ IJF, UK and 350 Main Street, Malden, MA O2I48, USA 


\section{The texts}

Our sources for the submission at Chester are numerous but relatively brief, and the earliest extant references to it are almost contemporary. Many are what I will term possible 'allusions' to the event rather than explicit descriptions of it.

\section{The pre-Conquest texts}

The earliest explicit notice of the submission occurs sub anno 972 (recte $\mathrm{AD}$ 973) in the D, E and F texts of the Anglo-Saxon Chronicle (that is, the 'Northern' recension) and in the related Annales Domitiani Latini, a Latin translation made at Canterbury and combined with the vernacular text in manuscript F. The annal begins by describing Edgar's consecration as king at Bath on Whit Sunday, 973, and the D text continues thus: ${ }^{2}$

${ }_{7}$ sona æfter pam se cyning gelædde ealle his scipfyrde [sciphere, E, F] to Leiceastre [Loegeceastre, E; Legerceastre, F], 7 pær him comon ongean .vi. cyningas, 7 ealle wið hine getreowsodon pæt hi woldon efenwyrhtan beon on sæ and on lande.

Non multo autem post rex congregat naualem exercitum et secum ducit usque Legeceastre. Cui occurrunt ibi .vi. reges et fidem dantes spondent se ei per omnia affuturos terra et mari.

And immediately after that the king took his whole fleet to Chester, and there six kings came to him, and all gave him pledges that they would be his allies (lit. fellow workers) on sea and on land.

Despite differences of exact wording and language, the four passages agree on the location of the submission (Old English Legacastir for Chester $)^{3}$ and the number of kings who submitted, but provide no further details, such as the names of the kings or their kingdoms.

2 The Anglo-Saxon Chronicle: a Collaborative Edition, ed. D.N. Dumville and S.D. Keynes, VI, MS. D, ed. G.P. Cubbin (Cambridge, 1996), p. 46; Two of the Saxon Chronicles Parallel, ed. C. Plummer, 2 vols (Oxford, I892-9), I, II9 (=E-text); The Anglo-Saxon Chronicle: a Collaborative Edition, I, Facsimile of MS. F: the Domitian Bilingual, ed. D. Dumville (Cambridge, I995), fols. 58v-59r; The Anglo-Saxon Chronicle: a Revised Translation, ed. D. Whitelock, with D.C. Douglas and S.I. Tucker (London, 196I, rev. 1965), pp. 76-7 (trans.). For the Latin version, see ASC 973 F, fo. 59r; F.P. Magoun, 'Annales Domitiani Latini: an Edition', Medieval Studies 9 (1947), pp. 235-95, at pp. 240-I; also idem, 'The Domitian Bilingual of the Old-English Annals: Notes on the F-text', Modern Language Quarterly 6 (1945), pp. 37I-80; and, D.N. Dumville, 'Some Aspects of Annalistic Writing at Canterbury in the Eleventh and Early Twelfth Centuries', Peritia 2 (1983), pp. 23-57.

3 For a discussion of the name, see J.McN. Dodgson, The Place-Names of Cheshire, V, English Place-Name Society 43 (Cambridge, 198I), pp. 2-7. 
To my knowledge, no other pre-Conquest English sources make explicit reference to the submission at Chester of 973. However, there are a number of Old English and Anglo-Latin texts which seem to allude to it, or at least describe Edgar's power in comparable terms. For example, Ælfric, abbot of Eynsham in the early eleventh century, may have made two possible allusions. Firstly, in a short passage in praise of Edgar in the 'Life of St Swithun' (written $992 \times$ I002), he stated: 4

And ealle pa cyningas pe on pysum iglande wæron, Cumera and Scotta, comon to Eadgare hwilon anes dæges, eahta cyningas, and hi ealle gebugon to Eadgares wisunge.

And all the kings who were on this island, of 'Cumbrians' and of 'Scots', came to Edgar in the course of one day, eight kings, and they all submitted to Edgar's rule.

This account refers to eight kings against the Chronicle's six, supplies their geographical provenance, and suggests that Ælfric regarded the submission as having constituted a single event ('in the course of one day'). A second reference occurs in Ælfric's 'Epilogue' to his work on the Book of Judges (written $1002 \times$ I005): ${ }^{5}$

And him God gewilde his wiðerwinnan a, ciningas and eorlas, pæt hi comon him to buton ælcum gefeohte, friðes wilniende, him underpeodde to pam pe he wolde, and he wæs gewurðod wide geond land.

And for him [Edgar] God willed that his enemies, kings and earls, came to him without any fighting, desirous of peace, [being] subjected to him in whatever he would, and he was honoured widely throughout the land.

Although this allusion is even less detailed, it emphasizes a further aspect, the peaceful nature of the submission or submissions. The reference to eorlas as well as kings may be significant, especially if it is taken to mean Scandinavian jarls rather than Anglo-Saxon ealdormen or earls.

4 Elfric. Lives of Three English Saints, ed. G.I. Needham (Exeter, 1976), p. 80; also, Aelfric's Lives of Saints, ed. W.W. Skeat, EETS 82 (London, I885), pp. 468-9; and, English Historical Documents (hereafter $E H D$ ), gen. ed. D. Douglas, I, trans. D. Whitelock, 2nd edn (London, 1979; repr 1996), p. 927.

5 The Old English Version of the Heptateuch. Alfric's Treatise on the Old and New Testament and his Preface to Genesis, ed. and trans. S.J. Crawford, EETS 160 (London, 1922), pp. 416-17; also $E H D$, trans. Whitelock, I, 928.

(C) Blackwell Publishers Ltd 200I Early Medieval Europe 200I Io (I) 
Another possible pre-Conquest allusion to the submission occurs in the so-called 'Ely' charter of Edgar, which is generally regarded as dubious by historians: ${ }^{6}$

Ego Eadgarus basileus dilecte insule Albionis subditus nobis sceptri Scotorum Cumbrorumque ac Brittonum et omnium circum circa regionum ...

... ic Eadgar cining eac purh his [=Godes] gife ofer Engla peode nu up aræred and he hæfð nu gewyld to minum anwealde Scottas and Cumbras and eac swylce Bryttas and eall pæt ðis igland him on innan hæfठ ...

Although the relationship between the Latin and Old English versions of this charter has not been satisfactorily determined, it has been argued that the latter is in the style of Ælfric, who perhaps wrote it c. 1006 . $^{7}$

The 'Northern recension' of the Chronicle also includes two poems in praise of Edgar, entered under the years 959 (DEF) and 975 (DE) respectively, and attributed to Wulfstan (d. IO23), archbishop of York and bishop of Worcester, who was Ælfric's contemporary and correspondent. ${ }^{8}$ Significantly, the first poem - which marks Edgar's accession on the death of his brother Eadwig - bears more than a passing verbal resemblance to the passage from Ælfric's Epilogue quoted above: ${ }^{9}$

God him eac fylste, pæt ciningas and eorlas / georne him to bugon. / And wurden underpeodde to pam pe he wolde. / And buton gefeohte eal he gewilde, / pæt he sylf wolde. / He wearð wide geond peodland, / swiðe geworðad,

6 'I, Edgar, ruler of the beloved island of Albion, subjected to us of the rule of the Scots and Cumbrians and the Britons and of all regions round about ...' (Latin); and, 'I, Edgar, exalted as king over the English people by His [God's] grace, and He has now subjected to my authority the Scots and Cumbrians and also the Britons and all that this island has inside ...' (Old English). See P.H. Sawyer, Anglo-Saxon Charters: An Annotated List and Bibliography (London, 1968), no. 779; for a suggestion of its authenticity, see C. Hart, The Early Charters of Eastern England (Leicester, 1966), no. 55.

7 A. McIntosh, 'Wulfstan's Prose', Proceedings of the British Academy 35 (1949), pp. Io9-42, at pp. I13, I28-9, n. 8; for a counter-argument, see Liber Eliensis, ed. E.O. Blake (London, I962), pp. 4I4-I5.

8 K. Jost, 'Wulfstan und die angelsächsische Chronik', Anglia 47 (I923), pp. IO5-23.

9 'God also supported him so that kings and earls / willingly submitted to him, / and were subjected to whatever he wished. / And without battle he brought under his sway all / that he himself wished. / He came to be, widely throughout the countries, / greatly honoured.': ASC 959 DEF (F contains the first part of this poem but omits the second poem entirely); The Anglo-Saxon Chronicle, ed. Whitelock et al., p. 75 (trans.). 
The second poem, quoted at the Edgar's obit (s.a. 975), also refers to submission: ${ }^{10}$

pæt aferan Eadmundes / ofer ganetes bað / cyningas hine wide / wurðodon swiðe / bugon to cyninge / swa wæs him gecynde.

Comparable with these Old English passages is the Latin description of Edgar's power by Byrhtferth of Ramsey in his Vita S. Oswaldi (written $995 / 7 \times 1005$, perhaps $997 \times 1002):^{\text {II }}$

Rex autem armipotens Eadgar, sceptris et diadematibus pollens, et iura regni bellica potestate regaliter protegens, cuncta inimicorum superba colla pedibus suis strauit; quem pertimuerunt non solum insularum principes et tyranni, sed etiam reges plurimarum gentium, ipsius audientes prudentiam, timore atque terrore perculsi sunt.

Similarly, the roughly contemporaneous Vita S. Dunstani by 'B' (composed $995 \times 1005)$ includes among a list of Edgar's achievements: 'reges et tyrannos circumquaque sibi subicere'. ${ }^{\text {I2 }}$

In addition to these Old English and Anglo-Latin pre-Conquest texts, Edgar's visit to Chester in 973 may also have been recorded by a contemporary Welsh chronicler. The extant medieval Welsh chronicles (Latin and vernacular) contain a brief reference to what must be the same event (s.a. 97I $=973)$, though there is some confusion as to its exact location. The $\mathrm{C}$ text of the Annales Cambriae gives the following short statement: Congregatio nauium in Urbe Legionum a rege Saxonum Eadgar ('The gathering of ships at Chester by Edgar king of the English'). ${ }^{{ }^{3}}$ The other extant version of the Annales covering this period (the $\mathrm{B}$ text) seems

Io 'Kings honoured him, the son of Edmund, / Far and wide over the gannet's bath, / And submitted to the sovereign, / As was his birth right.': ASC 975 DE; Anglo-Saxon Chronicle, ed. Whitelock et al., p. 77 (trans.).

II 'Moreover valiant king Edgar, powerful with sceptres and diadems, and royally protecting the laws of the kingdom with military power, has cast down at his own feet all the proud necks of his enemies; him, have they feared, not only the princes and tyrants of the islands but also the kings of many peoples, hearing of his prudence, they were overcome by fear and terror.' See The Historians of the Church of York and its Archbishops, ed. J. Raine, RS 7I, 3 vols (London, I879-94), I, 425. On the Vita, see M. Lapidge, 'Byrhferth and Oswald', in N. Brooks and C. Cubitt (eds), St Oswald of Worcester. Life and Influence (Leicester, 1996), pp. 64-83.

I2 Memorials of St. Dunstan, Archbishop of Canterbury, ed. W. Stubbs, RS 63 (London, I874), p. 37 .

13 Annales Cambrice (hereafter $A C$ ), ed. J. Williams (ab Ithel), RS 20 (London, I860), p. 19. The slight verbal echo found here in the Latin text of the Domitian Bilingual is not without parallel: note E. Phillimore, 'The Annales Cambrice and Old-Welsh Genealogies from Harleian MS. 3859', Y Cymmrodor 9 (I888), pp. I4I-83, at p. I59, n. 7.

(C) Blackwell Publishers Ltd 200I

Early Medieval Europe 200 I Io (I) 
to omit this event, ${ }^{\mathrm{I}}$ though it was translated into Middle Welsh in the three surviving vernacular chronicles. The following passage occurs in the Peniarth 20 recension of the Brut $y$ Tywysogyon, with variants from the other two texts: Blwydyn wedy hynny, y bu lynges vawr gan Edgar [var. Edwart], vrenhin y Saesson, ynGhaer Llion [var. Kaer Llion ar Wysc] ('The year after that, there was a great fleet with Edgar [Edward], king of the English, at Chester [Caerleon-on-Usk]'). ${ }^{\text {Is }}$ The Red Book of Hergest recension of the Brut gives the English king's name incorrectly as Edward. More significantly, the place to which Edgar brought his fleet Urbs Legionum in the Latin text - was thought to have been Caerleonon-Usk by two of the vernacular translators or their common source. This error is explicable since the Old Welsh for both Chester and Caerleon was Cair Legion, translating Urbs Legionum, and usually rendered Kaer Lleon in Middle Welsh. ${ }^{16}$ Despite the late date of their redaction, these Welsh accounts of Edgar's naval presence at Chester in 973 probably derive from an independent and contemporary witness, the lost 'Annals of St Davids' upon which all were ultimately based. ${ }^{17}$

Without onomastic evidence, it is impossible to identify with certainty the six or eight kings said to have submitted to Edgar in 973. At that date, the area roughly equating with modern Scotland was divided between two main Celtic political units: the Gaelic kingdom of Albu, Ælfric's 'Scots' ${ }^{18}$ ruled in 973 by Cinaed mac Maíl Choluim (d. 995);

I4 There is an erasure at the relevant point in the manuscript (London, Public Record Office E I64/I, p. II, line I of the first column) which is illegible on the photocopy which I have used, but may indicate that the Chester episode was there originally (a possibility supported by its occurrence in the vernacular Brutiau), or rather that the scribe had left out one annus before copying out the annal for 974 .

is Bruty Tywysogyon. Peniarth MS. 20 (hereafter ByT (Pen. 20)), ed. T. Jones (Cardiff, 194I) and Brut y Tywysogyon or The Chronicle of the Princes. Peniarth MS. 20 Version, trans. T. Jones (Cardiff, 1952), s.a. 971 (= 973); Brenhinedd y Saesson or The Kings of the Saxons (hereafter ByS), ed. and trans. T. Jones (Cardiff, 197I), s.a. 971 = 973; Brut y Tywysogyon or The Chronicle of the Princes. Red Book of Hergest Version (hereafter ByT (BT)), ed. and trans. T. Jones, 2nd edn (Cardiff, 1973), s.a. 973. The sixteenth-century translation of a lost Brut printed as David Powel's The Historie of Cambria, now called Wales (London, 1584), p. 62, states that Edgar 'did send a great navie to Caerlheon on Usc, which mostlie turned backe, without dooing anie notable act'. The last part of the statement is possibly Powel's addition rather than derived from the medieval exemplar.

${ }^{16}$ For the name, see Dodgson, The Place-Names of Cheshire, V, $2-7$.

17 The fact that the entry occurs in both $A C(\mathrm{C})$ and the vernacular chronicles supports the view that it was in the lost St David's annals. On the medieval Welsh chronicles, see K. Hughes, Celtic Britain in the Early Middle Ages: Studies in Scottish and Welsh Sources (Woodbridge, 1980); D.N. Dumville, 'The Welsh Latin Annals', in his Histories and Pseudo-Histories of the Insular Middle Ages (Aldershot, 1990), Essay III, reprinted from Studia Celtica I2-I3 (1977-8), pp. 46I-7.

I8 At this point, the word 'Scot' might still have the broader meaning of 'Irish' or 'Gael': M. Esposito, 'The Nationality of Johannes Duns Scotus and the Meaning of Scotus, Scottia, etc., in the Middle Ages', Hermathena 50 (1937), pp. 170-6; note also Alfric's Catholic Homilies. The Second Series, ed. M. Godden, EETS, 2nd Ser. 5 (Oxford, 1979), pp. 197-8. 
and the Brittonic kingdom of Strathclyde, Ælfric's 'Cumbrians', 19 probably ruled by Dyfnwal ab Owain (d. 975). In addition, there were several Scandinavian political units - the kingdom of the Isles including Man, the 'kingdom' of Galloway and the jarldom of Orkney - which may equate to Byrhtferth's insularum principes et tyranni, as well as smaller Celtic polities not necessarily ruled by 'kings' ${ }^{20}$ In 973 , Wales comprised as many as four kingdoms within which at least six dynasts exercised power. North Wales, including the kingdom of Gwynedd, was probably under the rule of Iago ab Idwal Foel (d. after 980), though his nephew Hywel ab Ieuaf was active from c. 974; while the kingdom of Deheubarth, comprising most of south Wales except the south-east, was ruled by Owain ap Hywel (d. 988), whose son Einion was also politically active and may have ruled over the region of Brycheiniog. ${ }^{21}$ The somewhat flexible political structure of south-east Wales was divided between the large kingdom of Morgannwg (formerly called Glywysing), ruled by Morgan Hen ab Owain (d. 974), and the smaller Gwent which was ruled by the 'new' dynasty of Nowy ap Gwriad. ${ }^{22}$ There is also evidence from the mid-tenth century of dynasts whose exact genealogical and political affiliations are not clear, although some at least may represent smaller or short-lived Welsh political units other than the main four. With the two Celtic kingdoms of Scotland, we would thereby have in total six known kingdoms with perhaps eight or more active dynastic members - a number which could be increased further if the smaller political units or the various Scandinavian kingdoms were added. Neither figure given in the pre-Conquest sources for the number of kings who submitted to Edgar is therefore impossible.

19 On the possible meanings of this word, see I. Williams, The Beginnings of Welsh Poetry, ed. R. Bromwich (Cardiff, 1980), pp. 7I-2; P.A. Wilson, 'On the Use of the Terms "Strathclyde" and "Cumbria", Transactions of the Cumberland and Westmorland Antiquarian and Archaeological Society, ns 66 (1966), pp. 57-92. Also more recently see C. PhythianAdams, Land of the Cumbrians: a Study in British Provincial Origins AD 400-II20 (Aldershot, 1996).

20 For example, the Cenél Loairn line of mormaers of Buchan or Moray who patronized the church of Deer in the late-tenth and early eleventh centuries and from whom Macbeth was descended: Hudson, Kings of Celtic Scotland, esp. pp. I33-4; K.H. Jackson, The Gaelic Notes from the Book of Deer (Cambridge, 197I), pp. 30, 45 .

2I For a discussion, see D.E. Thornton, 'Maredudd ab Owain (d. 999): the Most Famous King of the Welsh', Welsh History Review I8 (1996-7), pp. 567-91, at pp. 573-5. The last recorded member of the independent dynasty of Brycheiniog is Tewdwr ab Elise, $f$. 925-34: The Text of the Book of Llan Dâv reproduced from the Gwysaney Manuscript, ed. J.G. Evans and J. Rhys (Oxford, I893), pp. 237-9; Sawyer, Anglo-Saxon Charters, no. 425.

22 On this figure, see W. Davies, An Early Welsh Microcosm. Studies in the Llandaff Charters (London, 1978), pp. 95-6; D.E. Thornton, 'Predatory Nomenclature and Dynastic Expansion in Early Medieval Wales', Medieval Prosopography 20 (1999), pp. I-22, at pp. I8-19.

(C) Blackwell Publishers Ltd 200I

Early Medieval Europe 2001 Io (I) 


\section{Post-Conquest texts}

An allusion to the extent of Edgar's power occurs in the so-called 'Altitonantis charter', dated 964, but now generally accepted to be a forgery drawn up at Worcester during the episcopate of Wulfstan, perhaps in the early I090s. ${ }^{23}$ The charter opens thus:

Eadgarus Anglorum basileus omniumque regum insularum oceani que Brytanniam circumiacent cunctarumque nationum quae infra eam includuntur imperator et dominus ...

Edgar ruler of the English and emperor and lord of all the kings of the islands of the ocean which surround Britain and of all the peoples who are included within it ...

\section{Later it states:}

Mihi autem concessit propitia diuinitas cum Anglorum imperio omnia regna insularum oceani cum suis ferocissimis regibus usque Norregiam maximamque partem Hiberniae cum sua nobilissima ciuitate Dublina Anglorum regno subiugare.

Moreover the propitious Divinity conceded to me, together with the empire of the English, to subject to the kingdom of the English all the kingdoms of the islands of the ocean, with their most ferocious kings, as far as Norway and the greater part of Ireland, with its most noble city Dublin.

The claim that Edgar's imperium extended as far as Norway (presumably intended to include the Orkneys) as well as most of Ireland is quite unhistorical. It has been suggested that the claim about Ireland originated during the episcopate of bishop Patrick of Dublin (IO74-84), a Benedictine monk trained at Worcester under Wulfstan, ${ }^{24}$ and was

23 Sawyer, Anglo-Saxon Charters, no. 73I, and sources cited there. For some discussion, see E. Mason, St. Wulfstan of Worcester, c. I008-I095 (Oxford, 1990), p. 217; J. Barrow, 'How the Twelfth-Century Monks of Worcester Perceived their Past', in P. Magdalino (ed.) The Perception of the Past in Twelfth-Century Europe (London, 1992), pp. 53-74, at pp. 69-70; E. John, 'An Alleged Worcester Charter of the Reign of Edgar', Bulletin of the John Rylands Library 4I (1958-9), pp. 54-80; and, E. John, Orbis Britanniae and Other Studies (Leicester, 1966), pp. 240-I. Eric John argues that this document is based on an original charter of Edgar but underwent significant rewriting and interpolation during the late eleventh century.

24 Thus argues E. John, Land Tenure in Early England: a Discussion of Some Problems (Leicester, 1964), pp. 106-7; note also A. Gwynn, The Writings of Bishop Patrick 1074-1084 (Dublin, 1955), pp. 6-7. 
inspired by attempts to bring the Irish church under the control of Canterbury (Patrick had been consecrated by Lanfranc). The claim that Edgar's power extended over Dublin also occurs in the letter 'De matre sancti Eadmundi martyris' written $c$. II2O by Nicholas, prior of Worcester (III3-24), to the scholar Eadmer of Canterbury. ${ }^{25}$ Although neither of these Worcester documents mentions the Chester submission explicitly, Prior Nicholas added that Edgar had subjected eight subreguli, which echoes the passage in Ælfric's 'Life of Swithun' quoted above.

The earliest fully detailed references to the Chester submission occur in the 'Anglo-Norman' chronicle of the twelfth and later centuries. They are clearly related to the pre-Conquest material, though only that by Henry of Huntingdon (writing II29 $\times$ II54) is simply a direct translation of the entry for 973 in the Anglo-Saxon Chronicle, probably a text close to that of the surviving manuscript E. ${ }^{26}$ The earliest and most important accounts are those in John of Worcester's Chronicon ex chronicis and William of Malmesbury's Gesta regum. These accounts are clearly related to one another, but their complex textual histories render the nature of this relationship obscure. The Chronicon is now generally accepted, at least in its surviving form, to be the work of a Worcester monk called John active in the IIzOs and II3Os, though it had been commissioned originally by Bishop Wulfstan (d. I095); and its overall compilation can be located within the chronological range $1095 \times$ IIO6 II $40 \times$ II $43 .{ }^{27}$ However, the main scribe (CI) of the 'fair copy' in Oxford, Corpus Christi College, MS. I57 who copied the Chronicon down to I099 (up to p. 363) seems to have been working before $\mathrm{II} 22 \times \mathrm{II} 23 .{ }^{28}$ The

25 '... super omnem Angliam et Scottiam et uniuersas insulas circumquaque positas, et usque ad Dublinam Hiberniae ciuitatem, cuius etiam regem sibi subiugauerat, imperium potentissme protendit; in tantum ut dum monarchiam in Anglia solus possideret, octo subregulos in exteris regionibus subditos et sibi seruientes haberet': see Memorials of St. Dunstan, ed. Stubbs, pp. 422-3. See E. John, 'The Age of Edgar', in J. Campbell (ed.) The Anglo-Saxons (Oxford, I982), pp. I60-89 and 254-5, p. 255n.; Barrow, 'How the Twelfth-Century Monks of Worcester Perceived their Past', p. 70.

26 'Edgarus rex, tercio decimo anno regni sui, sacratus est in die Pentecosten apud Bahan. Inde uero post Pentecosten duxit exercitum suum ad Legeceastr'. Vbi uenerunt contra eum sex reges. Qui omnes eius dicioni subiecti sunt, et omnes illi domino debitam dederunt fidem se terra et mari seruituros ei ad eius imperium': Henry, Archdeacon of Huntingdon, Historia Anglorum. The History of the English People, ed. and trans. D. Greenway (Oxford, I996), pp. 322-3. Also, Henry's initial eulogy on Edgar (ibid., pp. 3I8-2I) is evidently based on the first poem in ASC 959 DE, above. For a discussion of Henry's use of ASC, see ibid., pp. xci-xcviii.

27 For these details, see The Chronicle of John of Worcester, ed. and trans. R.R. Darlington, P. McGurk and J. Bray, 3 vols (Oxford, I995- ), II, esp. p. lxxxi; see also M. Brett, 'John of Worcester and his Contemporaries', in R.H.C. Davis and J.M. Wallace-Hadrill (eds), The Writing of History in the Middle Ages: Essays presented to Richard William Southern (Oxford, I98I), pp. IOI-26.

28 M. Brett, 'A Note on the Historia Novorum of Eadmer', Sciptorium 33 (I979), pp. 56-8.

C) Blackwell Publishers Ltd 200I

Early Medieval Europe 2001 Io (I) 
relevant entry for the submission at Chester describes Edgar's coronation at Bath in 973 , and continues: ${ }^{29}$

Interiecto deinde tempore ille cum ingenti classe, septentrionali Brytannia circumnauigata ad Legionum Ciuitatem appulit, cui subreguli eius .viii., Kynath scilicet rex Scottorum, Malcolm rex Cumbrorum, Maccus plurimarum rex insularum, et alii .v., Dufnal, Siferth, Huuual, Iacob, Iuchil, ut mandarat, occurrerunt et quod sibi fideles et terra et mari cooperatores esse uellent, iurauerunt. Cum quibus die quadam scapham ascendit, illisque ad remos locatis, ipse clauum gubernaculi arripiens, eam per cursum fluminis De perite gubernauit, omnique turba ducum et procerum, simili nauigio comitante, a palatio ad monasterium sancti Iohannis baptiste nauigauit. Vbi facta oratione, eadem pompa ad palatium remeauit. Quod dum intraret optimatibus fertur dixisse tunc demum quemque suorum successorum se gloriari posse regem Anglorum fore, cum tot regibus sibi obsequentibus potiretur pompa talium honorum.

Then, after an interval, he sailed around the north coast of Wales [Britain] and came to the city of Chester. Eight underkings, namely Kynath king of the Scots, Malcolm king of the Cumbrians, Maccus king of many islands, and five others, Dufnal, Siferth, Huuual, Iacob, Iuchil, went to meet him, as he had commanded, and swore that they would be loyal to, and cooperate with, him by land and sea. With them, on a certain day, he boarded a skiff; having set them to the oars and having taken the helm himself, he skilfully steered it through the course of the River Dee, and with a crowd of ealdormen and nobles following in a similar boat, sailed from the palace to the monastery of St John the Baptist, where, when he had prayed, he returned with the same pomp to the palace. As he was entering, he is reported to have said to his nobles that each of his successors would only be able to boast that he was king of the English when, so many kings submitting to him, he would enjoy the pomp of such honour.

This passage forms the basis of most later accounts of the submission. ${ }^{30}$ Like the Anglo-Saxon Chronicle, John included a panegyric on Edgar

29 The Chronicle of John of Worcester, ed. and trans. Darlington et al., II, 422-4; C. Hart, 'The Early Section of the Worcester Chronicle', Journal of Medieval History 9 (1983), pp. 25I-3I5, at p. 256.

30 The Chronicle of Melrose, facs. ed. A.O. and M.O. Anderson (London, 1936), p. I5; Symeonis Monachi Opera Omnia, ed. T. Arnold, RS I89-90 (London, I882-85), II, I30-I; Aluredi Beverlacensis Annales, sive Historia de Gestis Regum Britannia, Libris IX, ed. T. Hearne (Oxford, I7I6), p. II2; Chronica Majistri Rogeri de Houdene, ed. W. Stubbs, RS 5I (London, I868-7I), I, 63; Polychronicon Ranulphi Higden Monachi Cestrensis, ed. C. Babington and J.R. Lumby, RS 4I, 9 vols (London, I865-86), VII, I6-I9. 
sub anno 959, except he based his text not directly on that of the Chronicle but on the Vita S. Dunstani by 'B' and the passage quoted above from Vita S. Oswaldi. ${ }^{3 \mathrm{I}}$

The Gesta Regum of William of Malmesbury also has a complicated textual history. ${ }^{32}$ Originally commissioned by Queen Matilda (d. III8), William's now lost original draft $\left(\mathrm{W}^{\mathrm{I}}\right)$ was probably completed II $24 \times$ II 25 and this was edited and abbreviated as a presentation copy (T) for the Empress Matilda in II26. Soon after, William prepared a new edition $\left(\mathrm{W}^{2}\right)$, including new material and word changes, and this formed the basis of the A version. Finally, during the period $\mathrm{II} 26 \times \operatorname{II} 35$, further revisions were made $\left(\mathrm{W}^{3}\right)$ upon which the $\mathrm{B}$ and $\mathrm{C}$ versions are based. The following account of the submission, for which characteristically no date is given, is based on the $T$ version, with the significant variants of A supplied in brackets:

Regem Scottorum Kinadium, Cumbrorum Malcolmum, archipiratam Mascusium, omnesque Uualensium regulos [reges Walensium, A], [quorum nomina fuere Dufnal, Giferth, Huual, Iacob, Iudethil, add A], ad curiam coastos uno et perpetuo sacramento sibi obligauit; adeo ut apud Ciuitatem Legionum sibi occurentes in pompam triumphi per fluuium [De, add A] illos deduceret. Vna enim naui impositos ipse ad clauum [proram, A] sedens remigare cogebat; per hoc ostentans regalem magnificentiam, qui subiectam haberat tot regum potentiam. [Denique fertur dixisse tunc demum posse successores suos gloriari se reges Anglorum esse, cum tanta honorum prerogatiua fruerentur, add $\mathrm{A}] .^{33}$

Kinad king of the Scots, Malcolm [king] of the Cumbrians, Mascusius the pirate king, and all the Welsh kings [whose names were Dufnal, Giferth, Huual, Iacob, Iudethil], he compelled to attend his court, and bound them to him by one perpetual oath, so much so that, when they all met him at Chester, he took them for a triumphal procession on the river [Dee]. For he set them in one boat, and made them row while he sat at the helm [prow], as a way of displaying the majesty of a king who held power of so many kings in subjection.

3I The Chronicle of John of Worcester, ed. and trans. Darlington et al., II, 4IO-I3, and 4I2-I3, n. 2; also, R.R. Darlington and P. McGurk, "The "Chronicon ex Chronicis" of "Florence" of Worcester and its Use of Sources for English History before 1066', Anglo-Norman Studies 5 (1982), pp. I85-96. For a different interpretation of the relationship between these texts, see Hart, 'The Early Section', esp. pp. 280, 293.

32 For what follows, see William of Malmesbury. De Gestis Regum Anglorum. The History of the English Kings, ed. R.A.B. Mynors, R.M. Thomson and M. Winterbottom, 2 vols (Oxford, 1998-9), II, xvii-xix, xxii.

33 William of Malmesbury, ed. Mynors et al., I, 238-40, also II, 132-3; also earlier Willelmi Malmesbiriensis Monachi De Gestis Regum Anglorum Libri Quinque; Historia Novella Libri Tres, ed. W. Stubbs, RS 90, 2 vols (London, I887-9), I, I65.

(C) Blackwell Publishers Ltd 200I

Early Medieval Europe 2001 Io (I) 
[Indeed, he is reported to have said that his successors would only be able to boast of being kings of England when they enjoyed so singular an honour.]

Though not reproduced as regularly as John's, William's does recur in other texts. ${ }^{34}$

A third version of the rowing incident, clearly derived from that by John of Worcester, is given by Roger Wendover in his Flores historiarum (I204 $\times$ I234, probably $c$. I23I) and thence by Matthew Paris. ${ }^{35}$ In addition, a further passage clearly related to those of John and William occurs in the twelfth-century Durham tract known as De Primo Saxonum et Normannorum aduentu, siue de eorundem regibus: ${ }^{36}$

Post hunc frater eius Eadgarus filius Eadmundi, cui .uiii. reges, scilicet Kynodus rex Scottorum, et Malcolm rex Cumbrorum, et Maccus plurimarum rex insularum, et alii .u. subiecti fuerant.

After that, his [Eadwig's] brother Edgar son of Edmund [was king], to whom eight kings were subjected, namely Kynod king of the Scots, and Malcolm king of the Cumbrians, and Maccus king of many islands, and another five.

Three names are given here and, although they are the same three as those in the T version of William's Gesta, the name-forms, notably Maccus, are closer to those given by John of Worcester. Scholarly opinion on the date of this tract has varied; ${ }^{37}$ but if the episcopal lists were 'up-to-date' when redacted, then the earliest extant version was

34 See, for example, The Historical Works of Gervase of Canterbury, ed. W. Stubbs, RS 73 (London, I879-80), II, 50; Petrus de Natalibus, Catalogus Sanctorum et Gestorum eorum ex diuersis voluminibus collectus (Venice, I516), bk XI, ch. LXV; and reproduced thence in Nova Legenda Anglie: As collected by John of Tynemouth, John Capgrave, and Others, and first printed, with New Lives, by Wynkyn de Worde, ed. C. Horstmann, 2 vols (Oxford, I90I), II, 530-I.

35 Rogeri de Wendover Chronica, sive Flores Historiarum, ed. H.O. Coxe, 5 vols (London, I84I-44), I, 4I5; Chronica Majora, ed. H.R. Luard, RS 57, 7 vols (London, I872-84), I, 466-7; Flores Historiarum, ed. H.R. Luard, RS 95, 3 vols (London, I890), I, $5 \mathrm{I} 3$.

36 The version in London, British Library, Cotton MS. Domitian VIII is edited in Symeonis Monachi Opera Omnia, ed. T. Arnold, RS 75, 2 vols (London, I882-5), II, 372; and from London, British Library, Cotton MS. Caligula A. VIII in Symeonis Dunelmensis Opera et Collectanea, ed. J.H. Hinde, Surtees Soc. 5I (I868), p. 208. Unedited versions of this tract can be found in Oxford, Magdalen College, MS. 53; Durham, Cathedral Library MS. B.II.53, fols. I40-50; and, Cambridge, Corpus Christi College, MS. 66, pp. 65-98.

37 H.S. Offler, 'Medieval Historians of Durham', in his North of the Tees. Studies in Medieval British History, ed. A.J. Piper and A.I. Doyle (Aldershot, I996), pp. II-I2, and 22, n. 23; E.B. Graves, A Bibliography of English History to 1485 (Oxford, 1975), p. 292; A.P. Smyth, Warlords and Holymen: Scotland AD 80-I000 (London, 1984), p. 232; D. Rollason, 'Symeon's Contributions to Historical Writing in Northern England', in D.W. Rollason (ed.), Symeon of Durham. Historian of Durham and the North (Stamford, I998), pp. I-I3, at p. II; D.W. Rollason, D. Gore and G. Fellows-Jensen, Sources for York History, The Archaeology of York I (York, I998), p. 26. 
probably written $1 \mathrm{I} 23 \times \mathrm{II} 28$, which is later than scribe $\mathrm{C}^{\mathrm{I}}$ of John's Chronicon. It is thus possible that the three names were taken from the Chronicon, a copy of which is known to have reached Durham during the period II $22 \times 1135$ (possibly II $22 \times$ II29), ${ }^{38}$ rather than constituting John's source. I have been able to find only one case where the De Primo Saxonum aduentu was directly employed by a later source. ${ }^{39}$ Similar passages, seemingly derived from the same sources, can be found in various late vernacular texts. For example, Geoffrey Gaimar, writing in the mid-twelfth century and doubtless drawing on earlier accounts, stated that Edgar ruled the land 'as an emperor' and compared him with Arthur, adding that $I l$ sul regnot sur tuz les reis / E sur Escoz e sur Gualeis ('He alone ruled over all the kings / And over the Scots and over the Welsh'). ${ }^{40}$

In addition, the names of the sub-kings can be found as witnesses to a number of alleged charters of King Edgar which have been rejected by historians as post-Conquest forgeries and cannot be treated as independent evidence. For example, the names of seven of the eight subreguli in John of Worcester's account were incorporated into the witness list of a forged charter of Edgar granting Sandwich to the church of Canterbury. ${ }^{4 \mathrm{I}}$ The names are not given consecutively, but the relative order reflects that of the medieval chronicles, and the name-forms correlate with those given by John. Similarily, the names Kinadius rex Albaniae and Mascusius archipirata, which occur as witnesses to the spurious charter of privileges by Edgar to Glastonbury abbey dated 971, ${ }^{42}$ derive from William of Malmesbury's account, and probably formed part of the original version of his De antiquitate Glastonie ecclesie (dated II $29 \times$ II39). ${ }^{43}$ Interestingly, the charter does not occur in the abbey's Liber terrarum ${ }^{44}$ and the two names are lacking in the version in the Gesta regum.

38 Brett, 'John of Worcester', pp. II9-22; A.J. Piper, 'Historical Interests of the Monks of Durham', in Symeon of Durham, ed. Rollason, pp. 30I-32, at pp. 320-I.

39 See R. Vaughan, 'The Chronicle attributed to John of Wallingford', in Camden Miscellany XXI, Camden Society, ns 90 (London, I958), pp. ix, 55.

40 L'Estoire des Engleis, ed. A. Bell, Anglo-Norman Text Society (Oxford, I960), p. II3; also Lestoire des Engles solum la Translacion Maistre Geffrei Gaimar, ed. and trans. T.D. Hardy, RS 7I, 2 vols (London, I888-9), I, I50, II, II4. Gaimar also claimed that the Welsh kings carried three swords as part of Edgar's wedding celebrations: L'Estoire, ed. Bell, p. I25; Lestoire, ed. and trans. Hardy, I, I66, II, I25.

4I Sawyer, Anglo-Saxon Charters, no. 808. Birch dated this charter to ' 966 for 972 or 973 ' (presumably on the basis of the names of Edgar's sub-kings), but Sawyer gives the range $963 \times 97$. Note also the comments of Hudson, Kings of Celtic Scotland, p. 99.

42 Sawyer, Anglo-Saxon Charters, no. 783. Sawyer's authorities are unanimous in regarding the charter as a forgery; but, Hudson regards it and its witness-list as genuine: Hudson, Kings of Celtic Scotland, pp. 99-IOo. On balance, the former interpretation seems the safer option.

43 The Early History of Glastonbury. An Edition, Translation and Study of William of Malmesbury's De Antiquitate Glastonie Ecclesie, ed. and trans. J. Scott (Woodbridge, I98I), pp. I22-7.

44 On which, see L. Abrams, Anglo-Saxon Glastonbury: Church and Endowment (Woodbridge, I996), esp. pp. I4-I5, 3I-4.

(C) Blackwell Publishers Ltd 200 I 
Before proceeding to examine the lists of names of the sub-kings and any broader significance of the events of 973 , it is necessary to examine the possible relationship between the two key post-Conquest texts discussed above, namely, those of John of Worcester and William of Malmesbury, and their connection with the pre-Conquest material. Historians have long recognized points of contact between these two texts and have postulated that the two men exchanged information and drew on 'common sources', including material associated with Worcester. ${ }^{45}$ With reference to the submission of 973 , both the $\mathrm{T}$ and A versions of William's Gesta have unique parallels with John's text. Thus, the T version echoes John's use of clauum, against proram in A. However, the A version is certainly the closer of the two, with the addition of the names of the six 'Welsh' kings, the river-name Dee and the final statement about Edgar's successors. Either this material was added by William when preparing his $\mathrm{W}^{2}$ edition, or it had been in $\mathrm{W}^{1}$ but was omitted as part of the process of abridgement underlying $\mathrm{T}$ (indeed, given that $\mathrm{T}$ was presented to the Empress, the reference to Edgar's successors was perhaps best excluded!). The verbal parallels between the two texts are evident and, since William tended to re-word his sources more frequently than John and probably made more than one research trip to Worcester (including during the time of Prior Nicholas, erstwhile correspondent of Eadmer, above), ${ }^{46}$ then it seems more likely that his account of the Chester submission was based either directly upon that of John or upon 'Worcester' material which is reproduced more faithfully in John's Chronicon. What, therefore, can be made of the passage preserved in the Chronicon?

Comparison of the texts suggests that the first sentence of John's account (like the whole of that by Henry of Huntingdon) is a translation of the Old English account in the Chronicle, with the number of kings increased to eight and their names inserted:

Interiecto deinde tempore, ille cum ingenti classe ... ad Legionum Ciuitatem appulit; cui subreguli eius octo ... occurrerunt, et quod sibi fideles et terra et mari cooperatores esse uellent, jurauerunt (John of Worcester).

$\ldots_{7}$ sona æfter pam se cyning gelædde ealle his scipfyrde to Leiceastre, ${ }_{7}$ pær him comon ongean .vi. cyningas, ${ }_{7}$ ealle wið hine getreowsodon pæt hi woldon efenwyrhtan beon on sæ and on lande (ASC).

This is perfectly possible since, although the relevant recension of the Chronicle which contains this annal had a northern provenance

45 Brett, 'John of Worcester', pp. II3-I7; William of Malmesbury, ed. Mynors et al., II, I3.

$4^{6}$ The Vita Wulfstani of William of Malmesbury, ed. R.R. Darlington (London, 1928), p. ix, and pp. 5I-2, 54, 56-7 (where William mentions Nicholas). 
(probably at York), the D text is now thought to have been compiled at Worcester during the IO5OS, perhaps under the guidance of Ealdred (d. I069), bishop of Worcester and archbishop of York, so that a version of this text could have been available there to John or to a predecessor. ${ }^{47}$ Furthermore, William of Malmesbury's account does not verbally parallel the Anglo-Saxon Chronicle at this point, but, like John of Worcester, he used the verb occurro, 'to go towards, meet', which may be a further echo between the two twelfth-century texts: if so, John's account must again have precedence since its occurrerunt translates comon ongean of the Chronicle.

John of Worcester's references to eight as opposed to six kings and to the Cumbrians and Scots recall the passage quoted above from Ælfric's 'Life of St Swithun'. Ælfric's passages may also be echoed in the second part of John's account of 973, that is, his description of the rowing episode: here he specifies that the rowing took place die quadam ('on a certain day'), which again resembles Ælfric's statement that the eight kings came to Edgar hwilon anes dages. These possible verbal connections - admittedly limited to a few short phrases - suggest that Ælfric’s passage deserves closer scrutiny: having stated that the eight kings came to Edgar in the course of one day, he says that they all bugon to Eadgares wisunge. This is translated above, no doubt in the sense intended, as 'submitted to Edgar's rule'. However, while it was used to mean 'to submit', the Old English verb bugan means literally 'to bow, bend, stoop'; and similarly, the noun wissung means 'direction, guidance, instruction', with the extended meaning of 'rule, government'. According to John of Worcester, die quadam Edgar boarded a skiff with the eight kings, and placed them at the oars and he himself held the clauus gubernaculi, 'the tiller of the rudder', and steered (gubernauit) the vessel along the Dee. The Latin noun gubernaculum literally means 'helm, rudder (of a boat)' but is more commonly used in its figurative sense of 'guidance, direction' and thus 'government, rule' - roughly the same range of meanings as Old English wissung. John's description conjures the image of the eight kings bending or bowing (to pull the oars) before Edgar who held the 'rudder', that is, in effect 'bowing to Edgar's guidance'. The fact that Edgar and other tenth-century English kings are often described in seemingly genuine charters as gubernator (that is, governor, but literally, 'steersman, pilot') 'of the other peoples' or 'of all Britain' or 'Albion' may also have influenced this choice of imagery..$^{48}$ It is thus possible that the account of the rowing episode, related or preserved by John of Worcester, represents a deliberately

47 ASC (D), ed. Cubbin, esp. pp. lxxviii-lxxix. For John's use of ASC, see Darlington and McGurk, "The "Chronicon ex Chronicis"'.

48 For example, Sawyer, Anglo-Saxon Charters, nos 668, 674, 679-8I, 685, 678-8 etc.

(C) Blackwell Publishers Ltd 200I Early Medieval Europe 2001 Io (I) 
nautical embellishment and expansion of Ælfric's words, inspired partly by the known naval character of the meeting at Chester and in part by the various meanings of Old English wissung and Latin gubernaculum. Thus, whereas Stenton followed William of Malmesbury in suggesting that the rowing episode was essentially a symbolic act on the part of the sub-kings, ${ }^{49} \mathrm{I}$ would argue that, while there is indeed symbolism in this passage, it was not the inspiration of Edgar himself but of a later writer either John or an earlier Worcester scholar.

In the light of this suggested analysis, it is possible to come to a better understanding of the list of kingdoms and kings. For instance, there is a definite growth of the list over time. The northern recension of the Chronicle simply states that there were six kings, and offers no kingdoms or personal names. Elfric increases the number of kings to eight and names the kingdoms for two ('of the Cumbrians and Scots'). By the late eleventh or early twelfth century, a tradition, associated with Worcester, appears to have developed that Edgar's power extended over kings of the islands (reflected in the Vita S. Oswaldi, Altitonantis charter and Prior Nicholas' letter). John of Worcester (or his 'Worcester' source) subsequently combined this tradition with the kingdoms given by $/$ Ælfric, ${ }^{50}$ and gives the names of the eight, leaving the remaining five without a kingdom. The process did not stop there. The A and later versions of William's Gesta reproduce John's list but add that the remaining five were all Welsh kings and give some interesting variant name-forms; and similarly, Wendover provides the specific names of the five kingdoms.

Although my foregoing discussion attempts to explain the development of the account of 973 given by John of Worcester, his source for the list of names remains unaccounted for, and the variant forms supplied by William of Malmesbury suggest that further analysis is warranted.

\section{The eight kings}

The central question remains: is the list of kings given by John and William a post-Conquest invention concocted to embellish the narrative, or did John and possibly William independently draw upon a now-lost account of 973 which gave the names of the eight kings and which, therefore, may preserve a genuine tradition? It is first necessary to identify the eight kings. Obviously, if some or all can be shown not to have been alive or ruling in 973 , then the reliability of the list must be

49 Stenton, Anglo-Saxon England, p. 370.

so Indeed, Byrhtferth's Vita states: 'non solum insularum principes et tyranni, sed etiam reges plurimarum gentium', which does echo John's insularum rex plurimarum. 
questioned and the likelihood that it is a late forgery increases. If, on the other hand, chronologically suitable identifications can be established, then must the list ipso facto be accepted as reliable or regarded as evidence that the post-Conquest chroniclers were able to forge a credible list?

\section{The kings of the Scots and Cumbrians}

Ælfric specifies 'Scots' and 'Cumbrians' among the eight kings who submitted to Edgar, and these rulers invariably begin the post-Conquest lists, perhaps under the influence of Ælfric's text..$^{52}$ Three names in the lists are Gaelic in origin: Kynath for Cinaed, Malcolm for Mael Coluim, and perhaps Dufnal either for Domnall, or Brittonic Dyfnwal (Old Welsh Dumnagual). The identification of these kings is hampered by the fact that the names were among the more commonly used Scottish dynastic names of this period.

Kynath rex Scottorum can be identified as the Cinaed mac Maíl Choluim, king of Albu 97I-95..$^{53}$ According to most regnal lists, Cinaed succeeded Cuilén mac Illduilb and ruled for a period of twenty-four years and two months: this tallies with the chronicles which date Cuilén's death to $97 \mathrm{I}$ and that of Cinaed to $995 .{ }^{54}$ It is worth noting that there are a number of post-Conquest accounts of a submission by Cinaed to Edgar in return for multiple gifts, including the region of Lothian,"5 which is dated sub anno 975 (probably for AD 974) by Matthew Paris but has been associated with the events of 973 by some

5I For some discussion of the problems of identifying early medieval Celtic dynasts, see D.E. Thornton, Kings, Chronologies, and Genealogies: Studies in Political History in Mediaeval Ireland and Wales, ch. 3, and 'Identifying Celts in the Past: Towards a Methodology' (both forthcoming).

52 For earlier discussions of these Scottish rulers and/or their involvement at Chester in 973 see: M.O. Anderson, Kings and Kingship in Early Scotland, 2nd edn (Edinburgh, 1980); Smyth, Warlords and Holymen, pp. 226-8, 232-3; A.A.M. Duncan, Scotland: The Making of the Kingdom (Edinburgh, I975), pp. 95-6; Hudson, Kings of Celtic Scotland.

53 The Annals of Ulster ( to AD IISI) (hereafter $A U$ ), ed. and trans. S. Mac Airt and G. Mac Niocaill (Dublin, I983), s.a. 994 = 995.I; W. Stokes, 'The Annals of Tigernach' (hereafter AT), Revue celtique I7 (1896), pp. 337-420, s.a. 995; Chronicum Scotorum. A Chronicle of Irish Affairs (hereafter $C S$ ), ed. and trans. W.M. Hennessy, RS 46 (London, I866), s.a. 993; The Annals of Clonmacnoise (hereafter AClon.), ed. D. Murphy (Dublin, I896), s.a. 988. For Cinaed's position in the royal genealogy of Albu, see Corpus Genealogiarum Hiberniae, I, ed. M.A. O'Brien (Dublin, 1962; rev. imp. by J.V. Kelleher, 1976), p. 328; J. Bannerman, Studies in the History of Dalriada (Edinburgh, I974), p. 66.

54 Anderson, Kings and Kingship, pp. 263, 267, 275, 283, 288 and 291; $A U$ s.a. $970=971.1 ; C S$ [969]. For an erroneous, shorter reign-length, see D. Broun, The Irish Identity of the Kingdom of the Scots in the Twelfth and Thirteenth Centuries (Woodbridge, I999), pp. I40-I, I66.

55 De primo saxonum aduentu in Symeonis Opera Omnia, ed. Arnold, II, 382; Matthew Paris's Chronica Majora, ed. Luard, I, 467-8; Flores historiarum, ed. Luard, I, 5I4; Vaughan, 'The Chronicle attributed to John of Wallingford', p. 55. On this episode, see M.O. Anderson, 'Lothian and the early Scottish kings', Scottish Historical Review 39 (1960), pp. 98-II2, at pp. $103-4$.

C) Blackwell Publishers Ltd 200I

Early Medieval Europe 200I Io (I) 
historians. ${ }^{56}$ The fact that Lothian had apparently been under Scottish control since the middle of the century makes Edgar's 'grant' look more like a formal acknowledgment of this control; ${ }^{57}$ and, in the light of evidence for raids into England by Cinaed, Edgar may have been seeking to secure peaceful border-relations. ${ }^{58}$

The other 'Scottish' king in the Anglo-Norman lists is Malcolm rex Cumbrorum, that is 'Mael Coluim, king of the Cumbrians' (of Strathclyde). Any attempt to understand the history of Strathclyde in this period is hindered by the fact that the kingdom has no surviving regnal lists nor, beyond the late ninth century, any royal genealogies. ${ }^{59}$ Some scholars, following the fourteenth-century chronicler John of Fordun, have regarded the kingship of Strathclyde in this period as the possession of the heir-apparent (tánaise) of the kingdom of Albu, and have thus considered the tenth-century rulers of Strathclyde as agnatic descendants of Cinaed mac Alpín. ${ }^{6}$ However, more recent historians have rejected this tánaise principle and instead derive the tenth-century rulers of Strathclyde patrilineally from the earlier British dynasty. ${ }^{61}$ It seems likely that Malcolm of the lists is to be identified with the Mael Coluim mac Domnaill rí Bretan Tuaiscirt, 'Mael Coluim son of Domnall (Dyfnwal), king of the Northern Britons', whose death is recorded for 997 in the Irish chronicles. ${ }^{62}$ There is a serious difficulty here in that in 973 Strathclyde seems to have been under the rule of Dyfnwal ab Owain whose death, while on pilgrimage in Rome or in clericatu ('in clerical life') is

56 Anderson, 'Lothian and the early Scottish Kings'; Smyth, Warlords and Holymen, p. 232; Stenton (Anglo-Saxon England, p. 340) has 'shortly after'; note also Duncan, Scotland, p. 96, n. 38. Matthew's date 975 should be corrected to 974 , as he dates the submission at Chester one year too late.

57 Thus argue Duncan, Scotland, pp. 95-6; Smyth, Warlords and Holymen, pp. 232-3; and Hudson, Kings of Celtic Scotland, pp. IOO-I.

58 Anderson, Kings and Kingship, pp. 252-3; Early Sources of Scottish History AD 500 to I286, trans. A.O. Anderson (Edinburgh, I922; rev. imp. Stamford, 1990), I, 5I2. For another, rather interesting, episode involving these two kings, see William of Malmesbury, ed. Mynors et al., I, 254-7.

59 As well as the works cited above (n. 19), see D.P. Kirby, 'Strathclyde and Cumbria', Transactions of the Cumberland and Westmorland Antiquarian and Archaeological Society, ns 62 (1962), pp. 77-94; Wilson, 'On the Use of the Terms "Strathclyde" and "Cumbria"; A. Macquarrie, 'The Kings of Strathclyde, c.400-Ior8', in A. Grant and K.J. Stringer (eds), Medieval Scotland. Crown, Lordship and Community: Essays presented to G. W. S. Barrow (Edinburgh, 1993), pp. I-19.

60 Fordun identified Malcolm as one Malcolmus filius Duffi as regulus Cumbriae, presumably regarding him as son of the Dub mac Maíl Choluim, king of the Scots, who died in 966: Johannis de Fordun Chronica Gentis Scotorum, ed. W.F. Skene, Historians of Scotland I (Edinburgh, I87I), p. I70; John of Fordun's Chronicle of the Scottish Nation, trans. F.J.H. Skene, Historians of Scotland 4 (Edinburgh, I872), p. I63; also Kirby, 'Strathclyde and Cumbria', p. 90. However, since no Mael Coluim mac Duib is named in any sources before Fordun, the identification is probably best rejected.

${ }_{61}$ Macquarrie, 'The Kings of Strathclyde', pp. 6 and I4-15; Hudson, Kings of Celtic Scotland, pp. $72-3$ and 173 .

${ }_{62}$ AU s.a. 996 = 997.5; CS [995]; AT [997]; AClon. s.a. 990. For this identification, see Early Sources, trans. Anderson, I, 478; Smyth, Warlords and Holymen, p. 227; Duncan, Scotland, p. 96; Macquarrie, 'The Kings of Strathclyde', p. I6. 
dated to 975, that is two years after the Chester submission. ${ }^{63}$ The date at which Dyfnwal succeeded to the kingship of Strathclyde is difficult to estimate: 962 has been suggested, though this is probably best rejected as it is based on the tanaise interpretation of succession; ${ }^{64}$ it is possible that he succeeded his father Owain during the late 930s. ${ }^{65}$ This would suggest that Dyfnwal was relatively old by the early 970s, and his death in Rome or in clericatu may indicate that by 975 , and possibly as early as $971,{ }^{66}$ he had abdicated in favour of his son Mael Coluim. The latter could therefore be identified with Malcolm rex Cumbrorum of 973, and Dyfnwal himself could be Dufnal, one of the 'other' kings named by John of Worcester and listed among the 'Welsh kings' by William of Malmesbury.

\section{The Welsh}

While neither the Old English accounts nor that of John of Worcester explicitly state that any of the kings who submitted to Edgar in 973 were from Wales, the location of the submission makes it likely that the Welsh were represented. Indeed, William of Malmesbury claimed that five (Dufnal, Giferth, Huual, Jacob and Judethil) were reges Wallensium; while Wendover and Matthew Paris were more specific, associating Dufnal with Demetia (Dyfed), and Siferth and Huwal with Wallia, as well as Maco with Monia (either Anglesey or Man). Onomastic analysis suggests that two or possibly three of the eight named kings were of Welsh origin: Huual for Modern Welsh Hywel, Jacob for Iago, and (more problematically) Iuchil. ${ }^{67}$ Only Iago can be located in other sources with any real certainty. He is probably identifiable as Iago ab Idwal Foel, who ruled the kingdom of Gwynedd and its dependent

${ }^{63} A U$ s.a. 974 (= 975.2); AT 975; CS [973]; ByT (RB) [975]; ByT (Pen. 20) s.a. 974 (= 975); ByS s.a. $974(=975)$.

64 Thus, Smyth (Warlords and Holymen, p. 224) has suggested 962 since it was the year when, according to the tánaise principle, Dub mac Mail Choluim would have vacated the kingship to become king of the Albu.

65 Owinus rex Cumbrorum was still alive in 934 (Opera Omnia, ed. Arnold, I, 76); but see Chronica Majora, ed. Luard, I, 455, and Flores historiarum, ed. Luard, I, 500 (Dunmail rex in 945); also Early Sources, trans. Anderson, I, 44I (Douenaldus rex who fl. c. 940/I); A. Macquarrie, The Saints of Scotland. Essays in Scottish Church History AD 450-I093 (Edinburgh, 1997), pp. 203-4; Duncan, Scotland, p. 96. The king of the Cumbrians said by Symeon of Durham to have fought at Brunanburh in 937 remains anonymous (Opera Omnia, ed. Arnold, I, 76, II, 93).

66 The date of Dyfnwal's abdication could have been as early as c. 971 if the Riderch ('Rhydderch') who slew Cuilén in that year was indeed his son; but, despite secondary statements to the contrary, there is no evidence that Riderch was king of Strathclyde at this point. It is also worth stressing that there is ambiguity as to his name: Marjorie Anderson stressed that the form Amdarch (not Radharc) is supported by the manuscripts: Anderson, Kings and Kingship, p. 6o; but see Broun, The Irish Identity, p. 137, n. 30.

${ }^{67}$ Any discussions of Welsh politics in the late tenth century (as well as of the Welsh element at Chester in 973 in particular) are still based on Lloyd's A History of Wales, I, 343-52. See also W. Davies, Wales in the Early Middle Ages (Leicester, 1982), pp. I24-5; eadem, Patterns of Power in Early Wales (Oxford, 1990), pp. 45-6; Thornton, 'Maredudd ab Owain'.

(C) Blackwell Publishers Ltd 200 I Early Medieval Europe 2001 Io (I) 
regions singly and (at times) jointly from $c .950$ until c. 980. Following the death of the great Hywel Dda in 950, Iago and his brother Ieuaf successfully re-asserted control in the north. As meibion Idwal, they appear in the chronicles as opponents of Owain, Hywel's son and successor to the southern kingdom of Deheubarth. Iago attested a charter of Eadred in 955, along with Owain and Morgan Hen of Morgannwg, but without (it would appear) his brother. ${ }^{68}$ Indeed, Iago is said to have imprisoned Ieuaf in 969 and, according to Brenbinedd $y$ Saesson, to have subsequently had him hanged. ${ }^{69}$ Iago was still active in 973 and does not disappear from the record until 979/980, so he could be identified with Iacob of the post-Conquest accounts of 973 .

The Hywel who attended Edgar in 973 cannot have been Hywel Dda ap Cadell, for he died over twenty years before the event. The most likely candidate is Hywel ab Ieuaf, nephew of the Iago ab Idwal Foel just discussed. The main problem with this identification is that, unlike his uncle, Hywel cannot be found with any certainty in our extant Welsh sources as active until after 973. However, J.E. Lloyd was mistaken to question this identification on the grounds that Hywel ab Ieuaf 'did not obtain power until $9799^{\prime}{ }^{\circ}$ In fact, Hywel's first appearance in the chronicles is only one year after the Chester submission: in 974, Iago is said to have been deprived of his regnum and Hywel to have ruled it 'through this victory'. ${ }^{71}$ As noted above, Iago imprisoned and possibly killed Hywel's father in 969; so Hywel may have been the leading representative of his segment of the dynasty from that date and travelled to Chester in this capacity in $973 . .^{72}$

The most problematic of the alleged Welsh subreguli of Edgar in 973 is Iuchil, since it has been difficult for both medieval and modern historians to determine the etymology of this name. The forms vary from Iuchil (John of Worcester), Iukil (Wendover) and Ulkil, Nichil and Inkil (confusion of minims, in the Chronicle of Melrose, Symeon of Durham and the Flores respectively) to Iudethil (William of Malmesbury). Possible Scandinavian etymologies appear to have suggested themselves to the medieval chroniclers. Thus, the form Ulkil in the Chronicle of Melrose is rendered as 'Ulfkil' by A.O. Anderson, presumably for O.N. Úlfkell. ${ }^{73}$ Similarly, the association of this name

68 Sawyer, Anglo-Saxon Charters, no. 566. See H. Loyn, 'Wales and England in the Tenth Century: the Context of the Athelstan Charters', Welsh History Review Io (1980-I), pp. 283-30I, at p. 298.

$69 A C(\mathrm{C})$ 969; $B y T$ (RB) [969]; ByT (Pen. 20) s.a. 967 (= 969); ByS s.a. 967 (= 969).

70 Lloyd, A History of Wales, I, 349, n. I05.

${ }^{71}$ For the various versions, see: $A C(\mathrm{~B}, \mathrm{C})$ 974; $B y T(R B)[974]$; $B y T$ (Pen. 20) s.a. 972 (= 974); ByS s.a. $972(=974)$.

72 For a notice of Hywel active before his father's death in 969, possibly as early as 954, see Trioedd Ynys Prydein: The Welsh Triads, ed. and trans. R. Bromwich, 2nd edn (Cardiff, 1978), pp. 150, I53; and cf. ByT (RB) [954]; ByT (Pen. 20) s.a. 952 (= 954); ByS s.a. 952 (= 954).

73 Early Sources, trans. Anderson, I, 478 and 479, n. I. 
with Westmorland by Roger Wendover and Matthew Paris has led to the suggestion that the forms Jukil and Inkil represent attempts to identify the name as the Scandinavian Jókell or Ingjaldr respectively. ${ }^{74}$ Stenton dismissed such an identification and stressed the Brittonic origin of the name, possibly the form Iudethil reflecting the Old Breton (and Old Cornish) Judicaël. ${ }^{75}$ The Old Welsh name Iudguaul (modern Idwal) has also been considered: A.O. Anderson thought our man was Idwal Foel who died in 942; and Lloyd thought Ieuaf to be a possibility, only to reject him on chronological grounds (he was deprived of his kingdom and possibly hanged in 969). ${ }^{76}$ The form Juchil may reflect a corrupt derivation in the English transmission of Iudgual, but it is worth noting that in other instances English sources (both pre- and postConquest) were able to give better, more recognizable renderings of this Welsh name. ${ }^{77}$ The only other roughly contemporary Idwal who may have been at Chester in 973 is said to have died in 980 and, in one manuscript, to have been Idwal Fychan ab Idwal Foel, that is, brother of Ieuaf and Iago 'meibion Idwal'. ${ }^{78}$

However, a better Old Welsh etymology for Iuchil, if read as Iuthil, might be Old Welsh Iudhail, modern Ithel (< Ithael). ${ }^{79}$ This name was particularly associated with the dynasties of south-east Wales in the early medieval period which were under the rule of Morgan 'Hen' (the Old) ab Owain at the time of the Chester submission. ${ }^{80}$ Morgan, who had ruled Morgannwg since $c .930$ and had attested charters of Athelstan, Eadred and Eadwig, is conspicuous by his absence on the Dee in 973; but he was perhaps a little too hen to undertake the journey to Chester, and he actually died in the following year. ${ }^{8 \mathrm{r}}$ His sons were called

74 W.G. Collingwood, Scandinavian Britain (London, I908; repr. Felinfach, 1993), pp. 218-19; F.M. Stenton, Preparatory to Anglo-Saxon England being the collected Papers of Frank Merry Stenton, ed. D.M. Stenton (Oxford, 1970), p. 219.

75 Ibid., p. 219, n. 6. Anderson, it should be added, did not favour a Norse etymology either. For the name Judicaël, note K.H. Jackson, Language and History in Early Britain (Edinburgh, 1953; repr. Dublin, 1994), p. 3II.

76 Early Sources, trans. Anderson, I, 478-9, n. 6; Lloyd, A History of Wales, I, 349, n. IO5.

77 William of Malmesbury, ed. Mynors et al., I, 206, 254; see the forms cited by Loyn, 'Wales and England', pp. 292-5. William of Malmesbury has Iudualus; the form Iudwalus also cited by William may be an error for Hywel. John of Worcester has Iuthuual (p. 380); ASC A 9I8 (=92I) has Ieopwel.

78 The identification occurs in some copies of the ByT (Pen. 20) and seems to have been accepted by Thomas Jones in his indices. Idwal Fychan is to be found in the genealogies as well: Early Welsh Genealogical Tracts, ed. P.C. Bartrum (Cardiff, 1966), p. IOI (=ABT $\$ 7 \mathrm{c})$. Powel's Historie of Cambria also gave this line of descent, adding that he was killed by Hywel, his nephew (that is, Hywel ab Idawl Ieuaf).

79 For Old Welsh forms, see $A C$ (A) s.a. 775 and 848; Genealogical Tracts, ed. Bartrum, p. I2; Book of Llan Dâv, ed. Evans and Rhys, pp. 406-7 (index): Iudhail, Iudhael, Ithail, and Ithael. Note also Jackson, Language and History, p. 346, including the eleventh-century epigraphic form IUTHAHELO.

8o See Lloyd, $A$ History of Wales, I, 338, 348; Davies, Wales in the Early Middle Ages, p. I03; eadem, An Early Welsh Microcosm, p. 95.

81 AC (C) 974; ByT (RB) [974]; ByT (Pen. 20) s.a. 972 (= 974); ByS s.a. 972 (= 974).

(C) Blackwell Publishers Ltd 200I

Early Medieval Europe $200 \mathrm{I}$ Io (I) 
Idwallon (noticed in the genealogies and chronicles) and Cadell, Cynfyn and Owain (in the Book of Llandaff only), but there is no Ithel. ${ }^{82}$ However, some late genealogies credit Morgan with a grandson of that name (by Idwallon) whose own son Gwrgan is mentioned in two Llandaff charters of $1038-40 .{ }^{83}$ Yet, it might be pushing the evidence too far to argue that the corrupt form Iuchil of the later English accounts represents this little-known grandson of Morgan Hen. Of the remaining Welsh kingdoms apparently not represented at Chester in 973, Deheubarth of Owain ap Hywel Dda throws up no suitably-named dynastic member for identification with this problematic name-form. ${ }^{84}$

Unless Iuchil is to be identified as the grandson of Morgan Hen of Morgannwg, then my analysis of the lists would suggest that the Welsh kings who allegedly submitted to Edgar were predominantly northern: southern Welsh dynasts such as Morgan, Owain ap Hywel of Deheubarth and his son Einion, as well as the minor kings of Gwent are conspicuous by their absence. Wendy Davies has suggested that the 'more powerful' southern kings boycotted the proceedings at Chester as they were in rebellion, but there is no contemporary evidence to support such conjecture. ${ }^{85}$ It is equally possible that the southern Welsh kings had found it more convenient to submit to Edgar at Bath during his coronation than journey to the more distant Chester.

\section{The Scandinavians}

The pre-Conquest texts do not state that Scandinavian 'kings' took part in the 973 submission, but Ælfric's reference to eorlas (jarls?) and that of

82 Two forged chronicles associated with Edward Williams, alias 'Iolo Morganwg', tantalizingly mention an Ithel ap Morgan Mawr as king of Morgannwg in the later 970s and 980s: The Myvyrian Archaiology of Wales: Collected out of Ancient Manuscripts, ed. O. Jones, E. Williams and W.O. Pughe, 2nd edn (Denbigh, I870), pp. 692-3, 718. The medieval chronicles contain the equivalent annal-entries, but make no reference to this Ithel; on balance, it would be prudent to discount this late and dubious material. For a discussion of one of these texts, see G.J. Williams, 'Brut Aberpergwm: a Version of the Chronicle of the Princes', Stewart William's Glamorgan Historian 4 (1967), pp. 205-20.

83 Genealogical Tracts, ed. Bartrum, pp. I05, I22; Book of Llan Dâv, ed. Evans and Rhys, pp. 258-9, 263. See K.L. Maund, Ireland, Wales, and England in the Eleventh Century (Woodbridge, 1991), p. 193; and W. Davies, The Llandaff Charters (Aberystwyth, 1979), p. I70. For this identification, see William of Malmesbury, ed. Mynors et al., II, I33.

84 Wendy Davies has suggested that Iuchil was 'some otherwise unidentified king of the south' but offers no onomastic etymology for the name: Patterns of Power, p. 75, n. 2. On Deheubarth generally in this period, see Thornton, 'Maredudd ab Owain'.

85 Davies, Patterns of Power, p. 75. The twelfth-century Vita S. Illtuti does describe the invasion of Morgannwg by Edgar shortly before his death, but this is best regarded as later hagiographical convention: Vitae Sanctorum Britanniae et Genealogiae, ed. and trans. A.W. Wade-Evans (Cardiff, I944), p. 228; G.H. Doble, The Lives of the Welsh Saints, ed. D.S. Evans, 2nd edn (Cardiff, 1984), pp. II7, I35. For another equally unreliable account of (in this case friendly) relations between Edgar and Morgannwg (under Morgan Hen), see Book of Llan Dâv, ed. Evans and Rhys, p. 248. 
Byrhtferth to insularum principes et tyranni could be taken to indicate that Scandinavian rulers from the Irish Sea region or beyond were involved. This was clearly assumed to be the case by the post-Conquest writers (to the extent of regarding Dublin as within Edgar's power), and John of Worcester's Maccus plurimarum rex insularum must fall into that category. On balance, a Norse etymology can be posited for John of Worcester's Siferth (ON Sigfrødr, or less likely Old English Sigefrið or Sigeferd) as well as for William of Malmesbury's alternative form Giferth (ON Gudrøðr). Most modern historians have followed the account of John of Worcester and its derivatives when seeking to identify this particular sub-king (see below), and I shall begin by considering these previous discussions of Siferth and return to Giferth below.

The apparent Norse character of the name (whether Siferth or Giferth) suggests that this sub-king came from one of the Scandinaviandominated regions of Britain. The problem here is that, following the reconquest of the Danelaw and Northumbria in the first half of the tenth century, there was no such region left on mainland Britain of which the ruler might owe submission to the English king, with the possible exception of Galloway. Beyond, there was the kingdom of Man and the Hebrides, and further afield, the Scandinavian towns of Ireland and the Scandinavian jarldom of the Orkneys, neither of which was under English overlordship in this period. A.O. Anderson identified 'Siferth' with the Orkney jarl Sigurðr Digri Hlövisson but then denied the historical value of the Anglo-Norman accounts, on the grounds that Sigurðr had not become jarl in $973 .{ }^{86}$ However, this identification is probably to be rejected on onomastic grounds. There have been a number of attempts to associate Siferth with Wales, although the medieval evidence is limited to Wendover's unreliable statement that Siferth and Huwal were reges Walliae. ${ }^{87}$ The basis for Siferth's Welsh connection seems to be the association of that name with Welsh rulers in the charter of 955 and the accounts of $973:^{88}$ since other names demonstrably not linked to Wales occur in both lists, this is hardly compelling. A thegn (minister) Sigeferð witnessed a series of Edgar's charters, ${ }^{89}$ including the 'Ely charter' of 970 which also mentions two thegns called Siferð and Siferth, as well as Mael Coluim king of Strathclyde. ${ }^{\circ}$

86 Early Sources, trans. Anderson, I, 478-9, n. 6.

87 For example, Robertson, Scotland under her Early Kings, II, 387. T. Stephens, The Literature of the Kymry: being a Critical Essay on the History of the Language and Literature of Wales during the Twelfth and Two Succeeding Centuries (London, I876), pp. 2I4-I5; J.C.R. Steenstrup, Normannerne: Danske og norske riger paa de brittiske øer $i$ Danevaldens Tidsalder, 4 vols (Copenhagen, I876-82), III, 20I; Collingwood, Scandinavian Britain, p. I85; Davies, Patterns of Power, p. 59.

88 For the charter cf. 955, see above, p. 68, and n. 68 .

89 Sawyer, Anglo-Saxon Charters, nos. 680, 681, 781 and 792.

90 Ibid., no. 779 .

(C) Blackwell Publishers Ltd 200I

Early Medieval Europe 200I Io (I) 
However, mere nominal correspondence is insufficient grounds for identification in these instances. Consequently, previous attempts to identify this Scandinavian sub-king based on the form Siferth have not proven successful. The possibilty that the variant form Giferth is to be preferred remains, and I shall reconsider this option below.

The other possible Scandinavian at Chester in 973 is variously called Maccus, Mascusius and Maco, of which the first form is probably to be preferred. He is described as plurimarum rex insularum (perhaps for Man and the Hebrides or Western Isles) by John of Worcester or as archipirata by William of Malmesbury. I have examined the name Maccus elsewhere and argued that it is not, as often stated, a 'corruption' of Old Norse Magnús, but rather is a characteristically HibernoScandinavian hybrid derived ultimately from the Old Irish noun macc ('son, boy'), which was a common element in early Gaelic anthroponymy, and turned into a personal name in the predominantly nonGaelic speaking context of the Scandinavian settlements of the British Isles. ${ }^{91}$ The figure Maccus plurimarum rex insularum named in the postConquest accounts of 973 may be identified with a Scandinavian leader called Maccus son of Harald active in the Irish Sea region in the early 970s, and often said to have died $c .977 . .^{92}$ The vernacular Welsh chronicles record for 97I that Anglesey, and specifically Penmon, was raided by a figure named variously in the vernacular versions as Marc mab Herald, Madoc vab Herald or Mactus vab Harald: that is, Marc or Madog or Mactus son of Harald. The Annales Cambriae offer no fourth alternative personal name but simply state that the raid was carried out $a$ flio Haraldi. ${ }^{93}$ The form Mactus suggests that it was the name Maccus with which the Welsh scribes were struggling here. ${ }^{94}$ Some Irish chronicles record that three years later a Maccus mac Arailt made a circuit of Ireland with a large host and raided Scattery Island (on the Shannon) from where he captured Ímar ua Ímair, the viking ruler of Limerick. ${ }^{95}$ While this Maccus is not associated with any specific 'kingdom' in these accounts, the Annals of the Four Masters do state that he made his

9r D.E. Thornton, 'Hey, Mac! The Personal Name Maccus, Tenth to Fifteenth Centuries', Nomina 20 (1997), pp. 67-98.

92 For a more detailed consideration of what follows, see my forthcoming paper provisionally entitled 'Tenth-Century Hiberno-Scandinavian Dynasties', where I hope to demonstrate that the usual 'around 977 ' dating for his death derives from modern historians' use of a late and unreliable Irish chronicle and has no value.

93 AC (B) 971; ByT (RB) [97I]; ByT (Pen. 20) s.a. 969 (= 97I); ByS s.a. 969 (= 97I).

94 This is made more likely by the fact that two of these same vernacular chronicles refer sub anno IO44 to the death of a Mactus Manach or Maccus Manach (possibly 'Maccus the Monk' or 'the Manxman'): see my 'Hey, Mac!', p. 86.

95 The Annals of Inisfallen (MS. Rawlinson B.503), ed. S. Mac Airt (Dublin, 195I), s.a. 974.2 refers to macc Arailt; and Annala Rióghachta Eireann. Annals of the Kingdom of Ireland, by the Four Masters (hereafter $A F M$ ), ed. and trans. J. O'Donovan, 7 vols, 2nd edn (Dublin, I856; rev. imp., I990), s.a. 972 (=974), calls him Maghnus mac Arailt, but I have shown that this is an error in O’Donovan's edition for Maccus mac Arailt: 'Hey, Mac!', pp. 76-7. 
initial circuit of Ireland co LLagmannaibh na nInnsed imbe ("with the "Lawmen" of the Isles along with him'), which is consistent with the title plurimarum rex insularum by John of Worcester.

Maccus son of Harald is often described in the secondary literature as having a brother, Gofraid mac Arailt, active between 972 and 989. This Gofraid is of interest since his personal name is probably derived from ON Gudrødr, which is a possible source for Giferth - William of Malmesbury's variant of Siferth. No text specifically states that Maccus and Gofraid were brothers, but rather their kinship has been inferred by historians on the basis of the shared patronymic. Their father may have been the Aralt mac Sitriucca meic Imair, king of Limerick, who was killed in 940.96 This would explain why in 974 Maccus attacked Ímar ua Ímair, who appears to have assumed the kingship of Limerick, perhaps in the 960s - doubtlessly at the expense of Aralt's sons. Gofraid makes one isolated appearance in the chronicles in 972, when he is said to have raided Anglesey, and then reappears in the 980 os when he seems to have been very active in the Irish Sea. ${ }^{7}$ His death is recorded in the Irish chronicles for 989, where he is entitled ri Innsi Gall ('king of the Isles of the Foreigners'), ${ }^{98}$ and in addition he may be the Gudrøðr konungr i Mön ('Guðrøðr, king in Man') mentioned twice in Njáls saga.9" Thus, if William of Malmesbury's form Giferth is to be preferred to John's Siferth, then he may have been Gofraid son of Harald, ${ }^{\text {Ioo }}$ an identification perhaps supported by the fact that his alleged brother Maccus is certainly among the kings said to have rowed Edgar on the Dee in 973.

While the identity of one (and possibly both) of these Scandinavian kings can be established with some certainty, it is less clear what their occurrence in the lists denotes. While the Anglo-Saxon Chronicle and the Welsh accounts show that Edgar's presence at Chester in 973 had a naval character, and later Anglo-Saxon and post-Conquest writers certainly emphasized the power of his fleet, ${ }^{\text {Ior }}$ there is no contemporary

${ }^{96}$ For example, William of Malmesbury, ed. Mynors et al., II, I32; G. Broderick, 'Irish and Welsh Strands in the Genealogy of Godred Crovan', Journal of the Manx Museum 8 (I980), pp. 32-8, at pp. 32, 34 .

97 Again, see Thornton, 'Tenth-Century Hiberno-Scandinavian Dynasties' (forthcoming).

${ }^{98}$ AU s.a. $988(=989.4) ; A T$,[989]; CS [987,]; AClon. s.a. 982; AFM s.a. 988.

99 Brennu-Njáls Saga, ed. E.Ó. Sveinsson, Islenzk Fornrit I2 (Reykjavík, I954), pp. 208, 224.

100 The possible identification of Giferth with Gofraid is rejected in William of Malmesbury, ed. Mynors et al., II, I33, but I do not think the arguments offered there are sufficient. Also, the interesting suggestion made there that Giferth represents the Welsh name Gruffudd is difficult to substantiate since no ruler of that name is known for the 970s. In fact, the name became more popular among Welsh dynasties in the following century and, furthermore, we might expect the more common post-Conquest Latin form Griffinus.

Iо $O$ One of the 'Wulfstan' poems in the Anglo-Saxon Chronicle (s.a. 975) claimed that no fleet or host (presumably of Vikings) was able to win booty for itself while Edgar ruled; and according to Anglo-Norman chroniclers, he made an annual circumnavigation of the island, by dividing his fleet (numbering as many as 3,600 vessels) into three parts covering the eastern, western and northern coasts: The Chronicle of John of Worcester, ed. and trans. Darlington et al., II, 424-7; William of Malmesbury, ed. Mynors et al., I, 256-7.

(C) Blackwell Publishers Ltd 200I

Early Medieval Europe 2001 Io (I) 
evidence that the viking rulers of Man and the Isles were subject to him or to any other tenth-century English king.

This survey suggests that at least six of the eight rulers named in the Anglo-Norman accounts of the Chester submission may be identifiable with figures mentioned in Celtic and other sources as active around 973. Of the remaining two names, one (Iuchil) cannot be explained with any satisfaction, and if it does reflect Old Welsh Iudhail, then no ruler of that name can be located satisfactorily in a suitable chronological position. Similarly, the name-form Siferth (while more easily explained onomastically) cannot be placed in any appropriate chronological or political context, but its variant Giferth may be derived as the name of the brother of one of the identified sub-kings.

\section{The submission of 973}

What therefore was the significance of the events of 973 as described in the various pre- and post-Conquest sources? The evidence of the preConquest sources demonstrates that Edgar did go to Chester in 973, that his presence there had a naval character, and that a number of other rulers (perhaps including those of Albu and Strathclyde) made some sort of submission to him. A comparison of texts suggests that the whole rowing incident may have been an embellishment, perhaps by John of Worcester, partly inspired by the naval character of the submission and partly by the wording of one Anglo-Saxon account. On the other hand, an analysis of the personal names of the sub-kings suggests that up to six of the eight can be identified with the names of rulers who flourished around the year 973 and could therefore have taken part in the submission, while the other two remain unidentifiable or, at best, of uncertain identity. Accordingly, the evidence of the lists of sub-kings cannot be so readily rejected. Other details might help to assess the reliability of the texts and, if accepted, elucidate the significance of the events.

Except for some Middle Welsh versions and that of Henry of Huntingdon, all accounts agree in placing the submission at Chester. As well as being a burh (rebuilt as such in 907), Chester was a port of some importance for the Irish Sea region and was easily accessible along the Dee. The existence of a mint there points to both an economic and a royal significance. Furthermore, its connection with Edgar was not limited to the submission of 973 . In 958 (when king of Mercia and Northumbria), he made the first recorded grant to St Werburgh's, now the cathedral, ${ }^{\mathrm{I} 2}$ and the mint at Chester seems to

Io2 Sawyer, Anglo-Saxon Charters, no. 667. The charter is dated to 858, presumably for 958 .

Early Medieval Europe 200I Io (I)

(C) Blackwell Publishers Ltd 200I 
have flourished especially during his reign. ${ }^{103}$ The choice of Chester for the submission may also have been partly political: despite the significant inroads made along the coast of North Wales during the ninth century and periodic submissions in the tenth, the Welsh kings were by no means totally subdued, and it may have been deemed necessary to impress the neighbouring Welsh with a display of power (naval and otherwise).

Although I have argued against the historicity of the rowing episode, it is worth exploring internal evidence of the two main accounts for material which might suggest otherwise. On a general level, the accounts of John of Worcester and William of Malmesbury concur, but they differ in points of detail. John describes the vessel used as relatively light (scapha, skiff), but William employs the less specific nauis. Both authors agree that the eight kings did the rowing. However, John states that Edgar took the helm (the rudder) himself (ipse clauum gubernaculi arripiens), thus locating him at the stern of the boat; and William follows this in the $\mathrm{T}$ version of the Gesta (above), but in the other versions he has Edgar sitting at the prow (ipse ad proram sedens). Furthermore, only John supplies any details about the route taken: they departed from the palatium and rowed to the monastery of St John the Baptist, from where, after praying, they returned to the palatium. That there was a minster church of St John in existence in 973 seems likely (though the surviving structures are later): in addition to a twelfthcentury tradition that the church was founded by Æthelred of Mercia and 'Wilfric, bishop of Chester' (probably an error for Wilfred of Leicester), therefore $692 \times 704,{ }^{104}$ its location near the Roman amphitheatre and the remains of early medieval crosses probably indicate earlier ecclesiastical activity on the site. ${ }^{\text {IOS }}$ However, the location, and therefore the possible existence, of John's palatium is less certain. One possible identification, 'Edgar's Field' (in the parish of St Mary on the Hill), is a late form, probably inspired by the supposed events of 973 , and accordingly the area has no demonstrable connection with Edgar. ${ }^{106}$ An

${ }^{103}$ R.H.M. Dolley, 'The Mint at Chester, I', Journal of the Chester and North Wales Architectural, Archaeological and Historical Society 42 (1955), pp. 4-5; N.J. Higham, The Origins of Cheshire (Manchester, 1993), p. I24.

104 The Annales Cestrienses date the founding to 689; see A. Thacker, 'Chester and Gloucester: Early Ecclesiastical Organization in Two Mercian Burhs', Northern History I8 (1982), pp. 199-2II, at p. 200.

105 The Victoria History of the County of Chester, ed. B. Harris and A.T. Thacker (London, 1987), I, 268.

${ }^{10} 6$ Dodgson, Place-Names of Chester, V, 53: the earlier name for this area was 'Kettles Croft' from the Old Norse personal name Ketill. For arguments in favour of this identification, see J.D. Bu'lock, Pre-Conquest Cheshire (Chester, 1970), p. 55; also note the comments of G. Webster, 'Chester in the Dark Ages', Journal of the Chester and North Wales Architectural, Archaeological and Historical Society 38 (I95I), pp. 39-48, at pp. 46-7.

(C) Blackwell Publishers Ltd 200I

Early Medieval Europe 2001 Io (I) 
alternative suggestion for the location of the 'palace' has been the royal manor at Farndon-on-Dee: ${ }^{107}$ yet this would involve a greater distance (about eight miles) from the church which may seem unreasonable. A third possiblility is that the word palatium may refer to the site of the burh itself. According to current archaeological interpretation, the burgal defences at 'late Saxon' Chester comprised the northern and eastern walls of the Roman fortress extended at the north-west and south-east corners respectively to the Dee and thereby employing the river itself for the western and southern defence. ${ }^{108}$ Thus, the church lay outside and to the south-east of the burh, but it would still have been possible to row from within the defences without having to cross the weir. A final option is that by palatium, John of Worcester was thinking (anachronistically) of the later Norman castle, though the relatively short trip might still have required traversing the weir. The location of John's so-called palatium is therefore unclear. Since our knowledge of early medieval Chester is far from perfect, it is possible that the remains of a structure identifiable with this supposed palatium are yet to be found but, in the interim, the lack of any certain location must add weight to my argument against the reliability of the rowing episode.

Even if the detail of the rowing incident is rejected as a later flight of linguistic fancy, the evidence of the pre- and post-Conquest accounts would seem to point to the events at Chester in 973 as representing a significant submission of Celtic and Scandinavian rulers to Edgar as their 'overlord' following his coronation at Bath. Indeed, such a submission could be interpreted as part of the growth of 'imperial' ideas at this time: that is, the coronation at Bath and the submission at Chester were elements in a series of phenomena which, when taken together, suggest that Edgar was aspiring to quasi-imperial status. ${ }^{109}$ These phenomena included appropriately imperial acts (the coinage reform of 973; or the grant of Lothian), terminology (in charters, legal documents etc.) and symbolic innovations (in architecture and iconography). In this respect, Edgar has been described not merely as overlord but as 'ruler of a British Empire, tenth-century style'. ${ }^{\prime \prime}$

${ }^{107}$ Bu'lock, Pre-Conquest Cheshire, p. 55; Higham, Origins of Cheshire, p. I24. On Farndon, see Stenton, Preparatory, pp. 3-4; Thacker, VCH Cheshire, I, 254, 265.

${ }^{10} 8$ For discussions of the burgal defences, see D.J.P. Mason, Excavations at Chester. 26-42 Lower Bridge Street 1974-6: the Dark Age and Saxon Periods, Grovesnor Museum Archaeological Excavation and Survey Reports 3 (Chester, 1985), pp. 36-9; A. Thacker, 'Early Medieval Chester: the Historical Background', in R. Hodges and B. Hobley (eds), The Rebirth of Towns in the West (London, I988), pp. II9-24, at pp. I2O-I; S.W. Ward, 'Saxon Chester: a Survey', in S.W. Ward and J.A. Rutter (eds), Excavations at Chester. Saxon Occupation within the Roman Fortress (Chester, 1994), pp. II5-24, at pp. II9-2I.

${ }^{109}$ J. Nelson, Politics and Ritual in Early Medieval Europe (London, 1986), pp. 302-3.

по Ibid., p. 303. 
Thus, with reference to terminology, it is worth quoting the opening to the proem of the contemporary Regularis Concordia, possibly drawn up c. $973:{ }^{\text {III }}$

Gloriosus etenim Eadgar, Christi opitulante gratia Anglorum ceterarumque gentium intra ambitum Britannicae insulae degentium rex egregius ...

Edgar the glorious, by the grace of Christ illustrious king of the English and of the other peoples dwelling within the bounds of the island of Britain ...

This should in turn be compared with the 'imperial' style adopted in many of Edgar's charters which might, at first glance, support this view: for example, phrases such as rex Anglorum ceterarum gentium in circuitu persistentium gubernator et rector, as well as totius Albionis gubernator et rector and totius Brittannie gubernator et rector. However, such phrases were not restricted to Edgar's charters, ${ }^{\text {II } 2}$ and we might wonder therefore to what extent the theory of such claims were realized in practice.

Returning to the texts themselves, the accounts which present the events at Chester in 973 as a submission are either the extended postConquest accounts or the pre-Conquest 'allusions', which might equally be read as more general statements about the extent of Edgar's overlordship and power (though Ælfric's hwilon anes dages is suggestive). Of the pre-Conquest material, only the Anglo-Saxon Chronicle (and the Welsh chronicles) explicitly refer to Chester and the year 973. Furthermore, and perhaps more significantly, most of the 'allusions' occur as part of extended passages in praise of Edgar, composed at least two or three decades after the king's death, by monastic authors who no doubt wished to elevate him because of his support for Benedictine reform. Edgar was a figure around whom legend developed very rapidly, so one must question to what extent the allusions may be regarded as reliable witnesses to the events of 973. An examination of the vocabulary of the texts is telling in this respect. The (contemporary?) Chronicle simply states that the (six) kings came to Edgar at Chester and promised to be his efen-wyrhtan, co- or fellow-workers, by sea and land. Admittedly, the 'Domitian Annals' do state that they also gave faith to him when doing so (dantes fidem) but this phrase has no parallel in the Old English

III Regularis Concordia. The Monastic Agreement of the Monks and Nuns of the English Nation, ed. and trans. T. Symons (London, I953), p. I.

II2 See, in general, H.R. Loyn, 'The Imperial Style of the Tenth-Century Anglo-Saxon Kings', History 40 (1955), pp. III-I5.

(C) Blackwell Publishers Ltd 200I Early Medieval Europe 200I Io (I) 
versions and is probably an addition. The Welsh chronicles offer no description of what Edgar and his fleet did at Chester. It is only in the various allusions that verbs like bugan and underpeodan or subicere occur, thus conveying the idea that the kings submitted to Edgar. This impression is reinforced by the post-Conquest texts with specific reference to 973 and Chester.

The submission of Celtic and Scandinavian rulers to an English king was not without precedent in the tenth century, ${ }^{\mathrm{II}}{ }^{\mathrm{I3}}$ and the various versions of the Anglo-Saxon Chronicle are important sources for these earlier submissions. In these cases, the idea of submission is clearly evident, especially following a defeat at English hands. However, I would argue that the events at Chester in 973 were of a different sort. Firstly, it may be significant that the Chester episode is limited to the three texts of the so-called 'northern recension', perhaps implying that its significance at the time was more local than the post-Conquest chroniclers would have us believe. In addition, the word efen-wyrhta, equal- or fellow-worker, suggests a degree of equality or cooperation lacking in the earlier 'submissions'. Indeed, there is an interesting parallel in the events of 945 , in this case recorded in most versions of the Chronicle. ${ }^{I 14}$ In this year, king Edmund is said to have ravaged all of Cumbraland (Strathclyde) and then to have let it to Mael Coluim king of the Scots on the condition (on pat gerad) that he should be Edmund's mid-wyrhta, co- or fellow-worker, 'both on sea and land'. Most commentators on this event have seen it as a rather over-ambitious attempt by Edmund to stabilize relations on his northern border and have been less impressed by the so-called grant than the Chronicle account would suggest. ${ }^{\text {II }}$ The likelihood of joint action by Edmund and Mael Coluim against a common enemy is perhaps conveyed in the word mid-wyrhta (suggesting future cooperation, should the need arise) and the verbal echo with the Chronicle account of 973 is thereby all the more intriguing. Furthermore, Edmund's supposed grant of Strathclyde is reminiscent of his son Edgar's seemingly empty grant of Lothian to Mael Coluim's son Cinaed made around, if not in, 973 (above). It therefore seems possible that what happened at Chester in 973 was less the submission by various Celtic and (possibly) Scandinavian rulers to

II3 Loyn, 'Wales and England'; also F.T. Wainwright, 'The Submission to Edward the Elder', History, ns 37 (1952), pp. II4-30.

${ }^{I I} 4$ ASC 945 ABDEF: Anglo-Saxon Chronicle, ed. Whitelock et al., p. 72 (trans.) The E and F versions omit the grant to Malcolm; cf. Wendover, Flores Historiarum, ed. Coxe, I, 398 for fuller account (Whitelock, EHD, I, 283); also, AC s.a. 946.

II Stenton, Anglo-Saxon England, p. 359; Pauline Stafford, Unification and Conquest: A Political and Social History of England in the Tenth and Eleventh Centuries (London, 1989), p. I2I; Smyth, Warlords and Holymen, pp. 205-6. For a more extended discussion, see Hudson, Kings of Celtic Scotland, pp. 83-6. 
Edgar as their 'imperial' overlord, than what might be termed in modern parlance a 'peace summit', organized by Edgar as primus inter pares following his coronation and intended to stabilize border relations and provide for future cooperation. ${ }^{\mathrm{II}}$

Department of History, Bilkent University, Ankara

${ }^{116}$ Earlier drafts of this paper were read by David Dumville and Huw Pryce, and I benefited from their useful comments. In addition, I am grateful to Alan Thacker for his editorial advice. However, all errors remain my own.

(C) Blackwell Publishers Ltd 200I

Early Medieval Europe 200I Io (I) 